\title{
Effects of various dietary fats on serum cholesterol, liver lipids and tissue pathology in rabbits
}

\author{
By J. P. FUNCH, G. KRISTENSEN AND H. DAM \\ Danish Fat Research Institute, Copenhagen \\ (Received I4 December I961-Revised 30 April 1962)
}

Rabbits fed on semi-synthetic diets without added cholesterol develop hypercholesterolaemia and a form of atherosclerosis when butter (Wigand, 1959; Funch, Krogh \& Dam, 1960) or hydrogenated fat (Wigand, 1959) is the sole dietary fat, whereas dietary vegetable oils or fat mixtures having high contents of polyenoic fatty acids increase the serum cholesterol levels only slightly and do not produce atheromatous lesions.

The experiment reported here was designed to study factors in butter that might be responsible for the observed hypercholesterolaemic and atherogenic effects in rabbits. It was supposed that the hypercholesterolaemic effect of butter might be related to its cholesterol content, its low content of unsaturated fatty acids or its high content of short-chain fatty acids or a combination of the last two factors.

The effect of a small amount of dietary cholesterol on serum cholesterol and atherosclerosis in rabbits was studied by comparing the effects of butterfat with those of cocoa butter or of cocoa butter to which cholesterol had been added in an amount equal to that found in butterfat. Cocoa butter was chosen because it is a natural fat similar to butterfat in iodine value and contents of saturated, oleic and total polyenoic fatty acids, the primary differences being the high contents of short-chain fatty acids and cholesterol in butterfat. The other dietary fats used in the experiment were butterfat supplemented with maize oil and two fats, fractionated cocoa butter and hydrogenated arachis oil, that contained almost no polyenoic fatty acids.

\section{EXPERIMENTAL}

Male rabbits, 6 months old, twenty-three albinos and thirty-one hybrids, purchased from a local dealer, were caged individually and distributed over six groups, nine in each group, so that the initial mean weights of all groups were nearly the same. In the groups the rabbits were matched for body-weight, and six rabbits, one from each group, of similar weight were given the same amount of food, the amount being limited to that consumed by the one eating least. Water was given ad lib. During the 6 weeks before the beginning of the experiment the rabbits were conditioned to the purified diet by gradually substituting it for a pulverized commercial rabbit food. During this period the purified diet contained $20 \%$ by weight of arachis oil. At the outset of the experiment, after $\mathrm{I}_{3}$ weeks and then again at 5 -week intervals $\mathrm{I} \mathrm{ml}$ of blood was collected from the marginal ear vein after an overnight fast. Cholesterol 
was determined in duplicate portions of the serum by the method of Herrmann (1957). The experiment lasted 38 weeks.

The dietary fats were stored at $-20^{\circ}$. As judged by the peroxide values determined, the fats were not oxidized during the experiment. The diets were made up twice weekly and kept in a refrigerator. The physical and chemical characteristics of the dietary fats are shown in Table I. Since some rabbits were reluctant to eat the basal diet used in a previous experiment (Funch, Krogh \& Dam, 1960), probably because it had a dry and dusty consistency when solid fat was added, this diet was modified and gelatin dissolved in water was included. The composition is shown in Table 2.

Table I. Iodine values, contents of polyenoic fatty acids and sterol, and coefficients of absorbability, of the dietary fats

\begin{tabular}{|c|c|c|c|c|c|c|c|}
\hline \multirow{2}{*}{$\begin{array}{l}\text { Group } \\
\text { no. }\end{array}$} & \multirow[b]{2}{*}{ Dietary fat } & \multirow{2}{*}{$\begin{array}{l}\text { Iodine } \\
\text { value } \\
\text { (Wijs)* }\end{array}$} & \multicolumn{3}{|c|}{$\begin{array}{l}\text { Polyenoic fatty acids* } \\
\text { (g/100 g fat })\end{array}$} & \multirow{2}{*}{$\begin{array}{c}\text { Sterol } \uparrow \\
\text { (g/roo g fat) }\end{array}$} & \multirow{2}{*}{$\begin{array}{c}\text { Coefficien } \\
\text { of absorb- } \\
\text { ability } t\end{array}$} \\
\hline & & & Dienoic & Trienoic & Tetraenoic & & \\
\hline $\mathfrak{I}$ & Butterfat§ & $3 \mathbf{I}$ & $\mathrm{I} \cdot 8$ & 0.4 & 0.3 & 0.28 & 98 \\
\hline 2 & Cocoa butter & 37 & $2 \cdot 4$ & $0 \cdot I$ & $\circ$ & 0.26 & 87 \\
\hline 3 & $\begin{array}{l}\text { Cocoa butter with } \\
\text { cholesterol\| }\end{array}$ & - & - & - & - & 0.54 & 85 \\
\hline 4 & $\begin{array}{l}\text { Fractionated } \\
\text { cocoa butter }\end{array}$ & 28 & 0.15 & $\circ$ & $\circ$ & - & 68 \\
\hline 5 & $\begin{array}{l}\text { Hydrogenated } \\
\text { arachis oil*** }\end{array}$ & 62 & 0.3 & $\circ$ & $\circ$ & - & $8 \mathrm{I}$ \\
\hline 6 & $\begin{array}{c}\text { Butterfat and } \\
\text { maize oil } \dagger \dagger\end{array}$ & 50 & $12 \cdot 8$ & 0.7 & 0.3 & - & 99 \\
\hline
\end{tabular}

* Determined by Mr Aa. Jart. The polyenoic fatty acids were determined by the alkali isomerization procedure described by the American Oil Chemists' Society (1958). Figures obtained by this method on hydrogenated fat may be used for guidance and comparison, but the validity of the absolute values remains to be established.

$\uparrow$ Determined by digitonin precipitation.

$\mp$ Calculated as: $\frac{\text { fatty acid ingested }- \text { faecal fatty acid }}{\text { fatty acid ingested }} \times 1$.

$\S$ Obtained by melting the butter and separating the butterfat and aqueous phases by gravity.

II Cholesterol (F. Hoffmann-La Roche \& Co. Ltd, Basle, Switzerland) was dissolved in cocoa butter by warming, so that the cocoa butter contained, as determined by digitonin precipitation, besides its natural sterols, an amount of cholesterol equal to that found in butterfat.

S m.p. $38^{\circ}$. The fractionation was carried out by Mr Aa. Jart (Jart, I959).

** m.p. $40^{\circ}-42^{\circ}$. Obtained from Aarhus Oliefabrik A/S, Aarhus, Denmark.

$\dagger+$ The mixture of butterfat and maize oil contained $20 \%$ maize oil.

Faeces from each group were collected on 6 consecutive days and stored in $96 \%$ (v/v) ethanol. After the entire quantity of faeces had been homogenized in ethanol by means of a Waring Blendor, duplicate portions were acidified with glacial acetic acid, and the total fatty acids were determined by the method of Blomstrand \& Lindquist (1955). The coefficient of absorbability of the different dietary fats was calculated according to the formula:

$$
\frac{\text { Fatty acid ingested - faecal fatty acid }}{\text { fatty acid ingested }} \times \text { Ioo. }
$$

No allowance was made for the faecal lipid arising endogenously rather than from ingested fatty acid, because the coefficients of absorbability were intended to be used 
only for comparison and because of the uncertainty of the assumption that the amount of 'metabolic fat' excreted on a high-fat diet is the same as that determined on a fatfree diet.

At the end of $3^{8}$ weeks' feeding, the rabbits were fasted overnight, anaesthetized by intravenous injection of $\mathrm{r} .5 \mathrm{ml}$ of a $6 \%$ solution of Nembutal sodium (Abbott) and killed by bleeding. The opened unstained aorta and pulmonary artery, from origin to ramification, with their valves were examined macroscopically.

Table 2. Percentage composition of the diets

$\begin{array}{lc}\text { Crude casein* } & 25 \\ \text { Cellulose } & 20 \\ \text { Sucrose } & 21 \cdot 5 \\ \text { Gelatin } & 5 \\ \text { Fatt } & 20 \\ \text { Vitamin mixture§ } & 0.5 \\ \text { Choline chloride } & 0.5 \\ \text { Salt mixturell } & 5 \\ \text { Potassium acetate } & 1 \cdot 5 \\ \text { Sodium chloride } & 0.6 \\ \text { Magnesium oxide } & 0.4\end{array}$

* Dairinex, obtained from Dansk Mejeri Industri \& Export Kompagni Ltd, Stege, Denmark.

$\uparrow$ Made from sawdust, obtained from Svenska Trämjölsfabrikerna (The Swedish Woodflour Mills), Göteborg, Sweden.

f See Table 1 .

$\S$ In addition to the vitamins listed in Table 2 of Funch, Nielsen \& Dam (1960), $500 \mathrm{~g}$ contained, at the expense of sucrose, 1500000 i.u. vitamin $A$ and 150000 i.u. vitamin $D_{3}$, supplied as $30 \mathrm{~g}$ of a stable powder (Rovimix $A+D_{3}$, Type 5o/5, F. Hoffmann-La Roche \& Co. Ltd, Basle, Switzerland).

II See Funch, Nielsen \& Dam (1960).

Since a significant amount of plaque formation was found primarily in the thoracic region of the aorta, the severity of atherosclerosis of this part only was graded (Funch, Krogh \& Dam, I960) on a scale of from 0 to 4 . Heart and samples of liver were fixed in $10 \%$ formalin (corresponding to $4 \%(\mathrm{w} / \mathrm{v})$ formaldehyde). Paraffin sections were stained with haematoxylin and eosin. Liver sections were also stained with van Gieson's stain for connective tissue. Material from all livers and hearts was cut on a freezing microtome. The sections were kept in warm water $\left(50^{\circ}-55^{\circ}\right)$ for $\frac{1}{2} \mathrm{~h}$ to melt any crystals of fats in the tissues and were afterwards stained for lipids with Sudan black. Unstained sections were inspected under crossed nicols for evaluation of the amount and location of birefringent material, such as cholesterol and its esters. The livers, except for the specimens taken for histological examination, were stored at $-20^{\circ}$ for chemical analysis.

A specimen of each liver was homogenized, and the lipid extracted with chloroformmethanol (2:I) by means of an Ultra-Turrax homogenizer (Janke \& Kunkel, K.G., Staufen i.Br., Germany). The total lipid content of the livers was determined in the filtered chloroform-methanol extract by the method of Folch, Lees \& Stanley (I957).

Because the distribution of the serum cholesterol values tended to skewness, statistical analysis was carried out on the logarithms. The geometric means of the original values were derived from the logarithms and are presented in Table 3 , along 
Table 3. Mean values with their standard errors for serum cholesterol of rabbits from the $\mathrm{I}^{\text {th }}$ to the $33^{\text {rd }}$ week of experiment with mean intensities of atheromatous lesions in the thoracic aorta, number of animals with atheromatous lesions in coronary arteries at the end of the experimental period of 38 weeks and mean body-weight changes during this period

\begin{tabular}{|c|c|c|c|c|c|}
\hline $\begin{array}{c}\text { Group } \\
\text { no. }\end{array}$ & Dietary fat* & $\begin{array}{c}\text { Serum } \\
\text { cholesterol } \dagger \\
\text { (mg/roo ml) }\end{array}$ & $\begin{array}{c}\text { Terminal grading } \\
\text { of thoracic } \\
\text { aorta } \ddagger\end{array}$ & $\begin{array}{c}\text { No. of rabbits } \\
\text { with atheromatous } \\
\text { lesions in coronary } \\
\text { arteries§ }\end{array}$ & $\begin{array}{l}\text { Body-weight } \\
\text { change } \\
\text { (g) }\end{array}$ \\
\hline I & Butterfat & $270 \pm 10 \%(6)$ & $I \cdot 5(6)$ & $4(6)$ & $+35 \mathrm{I}(6)$ \\
\hline 2 & Cocoa butter & $183 \pm 13 \%$ & $0.6(9)$ & $2(9)$ & $+\quad$ II (9) \\
\hline 3 & $\begin{array}{l}\text { Cocoa butter } \\
\text { with cholesterol }\end{array}$ & $307 \pm 17 \%(8)$ & $I \cdot 3(8)$ & $5(8)$ & $+64(8)$ \\
\hline 4 & $\begin{array}{l}\text { Fractionated } \\
\text { cocoa butter }\end{array}$ & $173 \pm 6 \%(7)$ & $0.2(6)$ & I (6) & $-537(6)$ \\
\hline 5 & $\begin{array}{l}\text { Hydrogenated } \\
\text { arachis oil }\end{array}$ & $448 \pm 13 \%(7)$ & $I \cdot O(4)$ & $3(4)$ & $-83(4)$ \\
\hline 6 & $\begin{array}{l}\text { Butterfat and } \\
\text { maize oil }\end{array}$ & $243 \pm 22 \%(6)$ & $0.3(6)$ & I (6) & $+320(6)$ \\
\hline
\end{tabular}

Figures in parentheses show the numbers of animals. See Table 4 for time and cause of death or slaughter, together with serum cholesterol values and degree of atheromatous lesions in the thoracic aorta, of the rabbits not surviving the experimental period.

* See Table I.

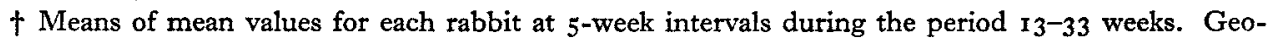
metric mean values.

\pm Assessed from a scale graduated from o to 4 (Funch, Krogh \& Dam, 1960).

$\S$ Estimated by microscopic examination of transverse sections taken at the base, at the middle and at the apex of the heart ventricles.

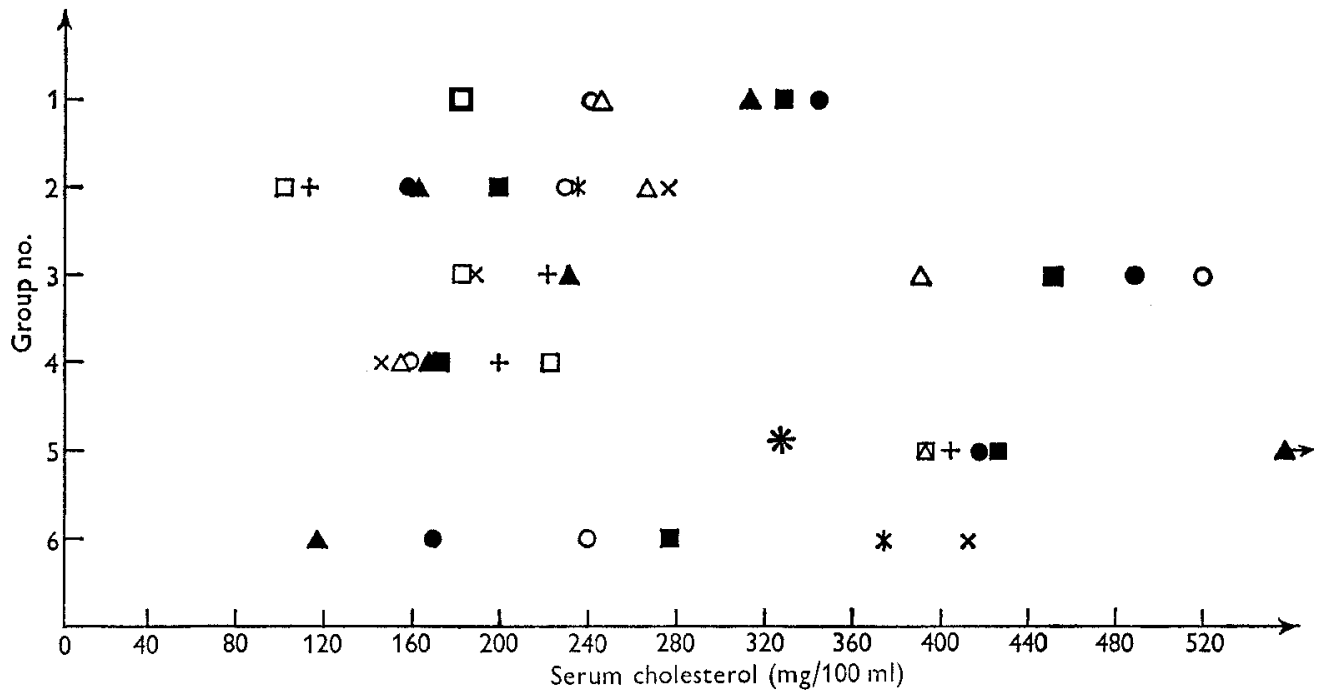

Fig. I. Mean values for serum cholesterol of each rabbit in the groups from the $13^{\text {th }}$ to the 33 rd week of experiment. $O, \bullet, \Delta, \Delta, \square, \square, \times,+$ and $*$ represent rabbits belonging to the same stratum; $\Delta \rightarrow=866 \mathrm{mg} / \mathrm{I} 00 \mathrm{ml}$.

with their approximate standard errors, each expressed as a percentage of the geometric mean. The stratification adopted in the design of this experiment did not exercise an important effect upon the results, as may be seen from Fig. I, in which the 
serum cholesterol value is given for each rabbit. Because of this, and the large number of missing values at the end of the experiment, the stratification was not taken into account in analysis of the results.

Because fractionated cocoa butter had a low coefficient of absorbability (Table $\mathrm{I}$ ), the result from the group given this fat was omitted from the statistical treatment.

\section{RESULTS AND DISCUSSION}

\section{Serum cholesterol levels and incidence of atherosclerosis}

Serum cholesterol was determined at the beginning of the experiment, after 13 weeks and then at 5 -week intervals over the 38 -week experimental period. An insufficient number of animals remained alive to allow for a comparison of the groups by means of the serum cholesterol values only at the end of the experiment. The means of the mean values for each rabbit during the period $13-33$ weeks were therefore used to

Table 4. Time and cause of death or slaughter, together with serum cholesterol values and degree of atheromatous lesions in the thoracic aorta of rabbits not surviving the experimental period of 38 weeks

\begin{tabular}{|c|c|c|c|c|c|c|c|}
\hline \multirow[b]{2}{*}{$\begin{array}{l}\text { Group } \\
\text { no. }\end{array}$} & \multirow{2}{*}{$\begin{array}{l}\text { Letter } \\
\text { mark } \\
\text { of the } \\
\text { rabbit }\end{array}$} & \multirow[b]{2}{*}{ Dietary fat* } & \multicolumn{2}{|c|}{ Serum cholesterol } & \multicolumn{2}{|c|}{ Death or slaughter } & \multirow[b]{2}{*}{$\begin{array}{l}\text { Atheroma } \\
\text { score }\end{array}$} \\
\hline & & & $\begin{array}{l}\text { Time } \\
\text { (weeks) }\end{array}$ & $\begin{array}{c}\text { Value } \\
(\mathrm{mg} / \mathrm{I} 00 \mathrm{ml})\end{array}$ & $\begin{array}{c}\text { Time } \\
\text { (weeks) }\end{array}$ & Cause & \\
\hline $\mathbf{I}$ & $\begin{array}{l}\mathbf{G} \\
\mathbf{H}\end{array}$ & Butterfat & $\begin{array}{l}28 \\
18\end{array}$ & $\begin{array}{r}1455 \\
139\end{array}$ & $\begin{array}{l}30 D \\
2 \text { I } S\end{array}$ & $\begin{array}{l}\text { Liver cirrhosis } \\
\text { Otitis media et } \\
\text { interna }\end{array}$ & $\begin{array}{l}2 \\
0\end{array}$ \\
\hline & I & & 13 & 545 & I3 $S$ & Liver cirrhosis & o \\
\hline 3 & I & $\begin{array}{l}\text { Cocoa butter } \\
\text { with cholesterol }\end{array}$ & 28 & 387 & $3 \circ S$ & $\begin{array}{l}\text { Otitis media et } \\
\text { interna }\end{array}$ & $\circ$ \\
\hline 4 & A & $\begin{array}{l}\text { Fractionated } \\
\text { cocoa butter }\end{array}$ & 33 & 201 & $34 S$ & $\begin{array}{l}\text { Otitis media et } \\
\text { interna }\end{array}$ & o \\
\hline & $\mathbf{B}$ & & 28 & 225 & $29 D$ & Enteritis & 0 \\
\hline & $\bar{I}$ & & 23 & 242 & $27 D$ & Unknown & 0 \\
\hline 5 & A & $\begin{array}{l}\text { Hydrogenated } \\
\text { arachis oil }\end{array}$ & $\longrightarrow$ & - & I I $S$ & Unknown & $\circ$ \\
\hline & B & & 33 & 531 & $37 D$ & Liver cirrhosis & 2 \\
\hline & $\mathrm{E}$ & & 33 & 667 & $37 D$ & Liver cirrhosis & 0 \\
\hline & G & & 28 & 229 & $33 D$ & Peritonitis & 0 \\
\hline & $\mathbf{H}$ & & 33 & 986 & $36 D$ & Liver cirrhosis & $\mathbf{I}$ \\
\hline 6 & $\mathrm{C}$ & $\begin{array}{l}\text { Butterfat and } \\
\text { maize oil }\end{array}$ & 13 & 94 & $16 D$ & Pneumonia & ○ \\
\hline & $\mathrm{E}$ & & 23 & 535 & $27 D$ & Pneumonia & o \\
\hline & $\mathbf{H}$ & & 28 & 189 & $28 D$ & Unknown & 0 \\
\hline
\end{tabular}

compare the effects of the dietary fats on the serum cholesterol levels. These values for serum cholesterol, mean intensities of atheromatous involvement in the thoracic aorta, number of rabbits showing atheromatous lesions in the coronary arteries at the 
end of the experiment and body-weight changes during this period are presented in Table 3. Time and cause of death or slaughter, together with serum cholesterol values and degree of atheromatous lesions in the thoracic aortas of the rabbits that did not survive the experiment, are listed in Table 4.

The rabbits given cocoa butter with added cholesterol equal to the amount found in butterfat (group 3) developed higher serum cholesterol values $(P<0.02)$ and more atherosclerosis than did those fed on cocoa butter without cholesterol (group 2), the effects being similar to those of butterfat alone (group r). Thus the effectiveness of butterfat in increasing serum cholesterol levels and incidence of atherosclerosis in rabbits must, apparently, be in part ascribed to its cholesterol content. Our results on rabbits agree with those found for human beings by Beveridge, Connell, Mayer \& Haust (1960), namely an increase in serum cholesterol concentration after the ingestion of small amounts of cholesterol added to a butterfat fraction from which the natural cholesterol had been removed. The hypercholesterolaemic effect of butter may, however, also be in part due to its low content of polyenoic fatty acids and possibly also to its high content of short-chain fatty acids.

In our experiment, the primary difference between the diets given to groups I and 3 was the high content of short-chain fatty acids in the butterfat. Apparently, the shortchain fatty acids did not enhance the hypercholesterolaemic effect of the cholesterol in the butterfat, since the mean serum cholesterol value of the rabbits given butterfat was similar to that of the controls given cocoa butter with cholesterol.

The presence of cholesterol in the dietary fat is not a prerequisite for the development of hypercholesterolaemia in rabbits, since the animals fed on diets containing hydrogenated arachis oil (group 5) developed serum cholesterol levels similar to or even higher than those of groups $\mathrm{I}(P<0.05)$ and $3(P<0.1)$. These results are in accordance with those of Lambert, Miller, Olsen \& Frost (1958) and Wigand (1959), who found marked hypercholesterolaemia in rabbits given cholesterol-free diets with hydrogenated coconut oil.

Whether the atherogenic effect of hydrogenated arachis oil was similar to that of butterfat or cocoa butter with cholesterol is uncertain, because five of the nine rabbits given hydrogenated arachis oil died before the end of the experiment (Table 4).

To compare the effect of a fat hydrogenated so as to contain essentially no polyenoic fatty acids with that of a fat from which the polyenoic fatty acids had been almost completely removed by fractionation (Jart, 1959), fractionated cocoa butter was also used in the experiment. The results in Table 3 show that the rabbits given fractionated cocoa butter (group 4) developed much lower serum cholesterol levels and less atherosclerosis than did those given hydrogenated arachis oil. In fact, fractionated cocoa butter did not raise the serum cholesterol level or the incidence of atherosclerosis above those obtained with the untreated cocoa butter. However, caution must be used in comparing the effect of fractionated cocoa butter on serum cholesterol and atherogenesis with that of the other dietary fats, since a relatively large portion of fractionated cocoa butter was not absorbed (Table $\mathrm{I}$ ). As a result of the low coefficient of absorbability of fractionated cocoa butter, the rabbits given this fat lost weight during the experiment (Table 3 ). 
Substitution of maize oil for $20 \%$ of the butterfat (group 6) caused only a moderate decrease in serum cholesterol concentration but markedly counteracted the atherogenic effect of the butterfat (Table 3).

\section{Results of autopsy, histological studies and determination of total lipid and cholesterol in the liver}

Xanthomata with ulceration were found over the heels of one rabbit given cocoa butter with added cholesterol (group 3).

No skin signs indicating deficiency of essential fatty acids were seen in any of the rabbits.

Atheromatous lesions in arteries other than the aorta. With marked atheromatous lesions in the aorta we usually also found lesions in other arteries, such as the brachiocephalic, the subclavian, the common carotid, the coronary and the pulmonary artery. Atherosclerosis in the aorta was associated with a conspicuous deposition of lipid on its semilunar valves and on the cardiac mitral valve. However, no atheromatous lesions were found on the valves or in the first $0.5 \mathrm{~cm}$ of the pulmonary artery. Around the orifices of the coronary arteries atheromatous lesions often formed a pad-like protuberance.

Table 5. Pathological changes, and total lipid and cholesterol, in the livers of rabbits after 38 weeks on experiment

\begin{tabular}{|c|c|c|c|c|c|}
\hline $\begin{array}{l}\text { Group } \\
\text { no.* }\end{array}$ & Dietary fat $\dagger$ & $\begin{array}{l}\text { Mean degree } \\
\text { of lipid } \\
\text { accumulation } \ddagger\end{array}$ & $\begin{array}{l}\text { Mean degree of } \\
\text { connective } \\
\text { tissue pro- } \\
\text { liferation } \S\end{array}$ & $\begin{array}{l}\text { Total lipid\|| } \\
\text { (g/I0o } \mathrm{g} \\
\text { liver) }\end{array}$ & $\begin{array}{l}\text { Cholesterol| } \\
\text { (g/100 } \mathrm{g} \\
\text { liver) }\end{array}$ \\
\hline I (6) & Butterfat & $1 \cdot 2$ & 0.3 & $8 \cdot 0 \pm I \cdot 0$ & $I \cdot 6 \pm 0 \cdot 5$ \\
\hline $2(9)$ & Cocoa butter & $2 \cdot 0$ & 1.7 & $8.2 \pm 0.4$ & $2 \cdot 3 \pm 0 \cdot 2$ \\
\hline $3(8)$ & $\begin{array}{l}\text { Cocoa butter } \\
\text { with cholesterol }\end{array}$ & $3^{-I}$ & $r \cdot 9$ & $10.8 \pm 0.9$ & $3.8 \pm 0.5$ \\
\hline $4(6)$ & $\begin{array}{l}\text { Fractionated } \\
\text { cocoa butter }\end{array}$ & $2 \cdot 2$ & $I \cdot 3$ & $8 \cdot 0 \pm 0.8$ & $2 \cdot 7 \pm 0.6$ \\
\hline $5(4)$ & $\begin{array}{l}\text { Hydrogenated } \\
\text { arachis oil }\end{array}$ & $2 \cdot 3$ & $I \cdot 2$ & $7.3 \pm 0.3$ & $I \cdot 7 \pm 0.3$ \\
\hline $6(6)$ & $\begin{array}{l}\text { Butterfat and } \\
\text { maize oil }\end{array}$ & $I \cdot O$ & o & $5.9 \pm 0.7$ & $0.7 \pm 0.1$ \\
\hline
\end{tabular}

* Figures in parentheses show the numbers of animals.

+ See Table $\mathrm{I}$.

I Assessed from a scale graduated from o to 4 after staining with Sudan black.

$\S$ Assessed from a scale graduated from o to 4 after staining with van Gieson's stain.

II Arithmetic mean values with their standard errors.

The coronary arteries from all the hearts were examined microscopically. Transverse sections were taken at the base, at the middle and at the apex of the ventricles.

A detailed description of the appearance of atheromatous lesions in the arteries of rabbits is not given here, because it would agree with that given by Anitschkow (1933). Atheromatous lesions do not occur uniformly through the whole extent of the arteries, and we therefore did not attempt to assess the exact extent of the lesions in the coronary arteries by inspecting transverse sections. Nevertheless, as can be seen from 
Table 3, a correlation was found between the incidence of atherosclerosis in the coronary arteries and the grading of lesions in the thoracic aorta. The atheromatous plaques were most commonly found in the small and medium-sized branches of the coronary arteries, where they often involved the whole circumference of the arterial wall (Pl. $\mathrm{r} a, b)$. In the larger branches of the coronary arteries the plaques, if present, generally involved only part of this circumference.

When unstained sections cut on a freezing microtome were inspected under crossed nicols, the plaques appeared light against a dark background. This property indicated the presence in the plaques of birefringent material, such as cholesterol and its esters.

Liver. Macroscopically abnormal livers were found in all the rabbits given butterfat, cocoa butter with and without added cholesterol, fractionated cocoa butter or hydrogenated arachis oil, and in two rabbits receiving butterfat supplemented with maize oil. The livers had a pale yellowish-tan colour, indicating infiltration of lipid. Some livers had an irregular surface and a firm indurated consistency, indicating replacement of the parenchymal cells by fibrous tissue. The central zone of the lobules was distinctly more yellow than the peripheral part. Moderate ascites and icterus occurred in some rabbits with grossly indurated livers. The lesions in the livers were so advanced in two rabbits given the diet containing butterfat and in three rabbits given the diet containing hydrogenated arachis oil that they died before the end of the experiment (cf. Table 4). In the butterfat-maize-oil group the livers of four out of six animals appeared macroscopically normal.

The macroscopic signs of lipid accumulation and connective tissue proliferation were verified by histological examination of liver sections and chemical determination of total lipid and cholesterol in the liver. A summary of these findings is provided in Table 5. The pathological changes in the livers were most advanced in the rabbits given the diet containing cocoa butter with added cholesterol (group 3) and least advanced in those given the diet containing butterfat supplemented with maize oil (group 6). The advanced pathological changes were correlated with high levels of total lipid and cholesterol in the livers (group 3), and the slight pathological changes with low levels of total lipid and cholesterol (group 6).

The early stages in the sequence of pathological changes are illustrated in Pl. $2 d$. The cells in the central zones of the lobules appeared light in the samples stained with haematoxylin and eosin or with van Gieson's stain. The light appearance of the cells indicated an infiltration of lipid that had been dissolved during dehydration before embedding in paraffin. This was verified by staining for lipid with Sudan black in sections cut on a freezing microtome (Pl. $2 a, b$ ). When unstained sections were inspected under crossed nicols the lipid-infiltrated areas appeared light against a dark background ( $\mathrm{Pl} .2 \mathrm{c}$ ). This probably indicates the presence of birefringent material such as cholesterol and its esters.

The lipid-laden cells were swollen and the adjacent sinusoids were compressed. The nuclei of some of the distended cells showed degenerative changes, such as hyperchromatosis of the nuclear wall or karyorrhexis. In some instances the nuclei had disappeared and the cells were necrotic. Along with the degenerative processes 
various stages of increase in the amount of connective tissue were seen. These changes were primarily confined to the centre of the lobules. The initial stages of increase in connective tissue in the liver are illustrated in Pl. $2 d$, in which a condensation and thickening of reticular fibres can be seen. Pl. $2 e$ illustrates a more advanced case where true proliferation of fibrous tissue, pseudolobulation and cirrhosis had occurred.

It is uncertain whether the lipid accumulation was due primarily to a fatty infiltration (steatosis) or a fatty degeneration (phanerosis). Apparently, however, the initial step was an infiltration of lipid and in particular an infiltration of cholesterol into the cells, preferentially into those located centrolobularly. This assumption is based on the fact that the nuclei of several lipid-laden cells appeared normal, particularly at the periphery of the focal accumulation of lipid. The cellular destruction may have been the result of the interference with blood supply, which the distended cells caused by compressing the adjacent sinusoids. Ultimately, the degenerated cells were replaced by connective tissue.

\section{SUMMARY}

I. The object of the experiment reported here was to study factors in butterfat that may affect the level of serum cholesterol and the incidence of atherosclerosis in male rabbits pair-fed on semi-synthetic diets containing $20 \%$ fat. The rabbits, 6 months old, were distributed over six groups of nine animals each. Butterfat with or without maize oil, cocoa butter with or without cholesterol equal to that found in the butterfat, and two other fats, fractionated cocoa butter and hydrogenated arachis oil, deprived of polyenoic fatty acids, were given to rabbits for 38 weeks. Serum cholesterol concentrations were measured at the outset, after 13 weeks and then at 5 -week intervals. Levels of total lipid and cholesterol were determined in the livers. Anatomical observations were made on the aortas and pulmonary arteries and their valves, on the coronary arteries and on the livers.

2. The primary differences between butterfat and cocoa butter are the amounts of cholesterol and short-chain fatty acids in butterfat. Cocoa butter with added cholesterol equal in amount to that present in butterfat raised serum cholesterol levels and the incidence of atherosclerosis more than did cocoa butter without added cholesterol and to about the same degree as did butterfat. It is concluded that, besides the low content of polyenoic fatty acids, the cholesterol content had a major responsibility for the hypercholesterolaemic and atherogenic effect observed in rabbits given butterfat. The presence of short-chain fatty acids apparently did not enhance the hypercholesterolaemic effect of the cholesterol in butterfat.

Cholesterol in the diet, however, is not a prerequisite for the development of hypercholesterolaemia in rabbits, since hydrogenated arachis oil gave rise to serum cholesterol levels similar to or even higher than those obtained on diets containing butterfat or cocoa butter with added cholesterol.

Substitution of maize oil for $20 \%$ of the butterfat decreased the serum cholesterol content only moderately, but markedly reduced the incidence of atherosclerosis.

3. High contents of cholesterol in the livers were associated with centrolobular degeneration and connective-tissue proliferation 


\section{REFERENCES}

American Oil Chemists' Society (1958). Official and Tentative Methods of Analysis, 2nd ed., rev. to 1958. 1946-58. Cd 7-58. Chicago: American Oil Chemists' Society.

Anitschkow, N. (1933). In Arteriosclerosis. A Survey of the Problem, p. 271. [E. V. Cowdry, editor.] New York: The Macmillan Co.

Beveridge, J. M. R., Connell, W. F., Mayer, G. A. \& Haust, H. L. (r960). F. Nutr. 7r, 6r.

Blomstrand, R. \& Lindquist, B. (1955). Helv. paediat. Acta, ro, 627.

Folch, J., Lees, M. \& Stanley, G. H. S. (1957). F. biol. Chem. 226, 497.

Funch, J. P., Krogh, B. \& Dam, H. (1960). Brit. F. Nutr. 14, 355.

Funch, J. P., Nielsen, E. \& Dam, H. (1960). Brit. F. Nutr. I4, I.

Herrmann, R. G. (1957). Proc. Soc. exp. Biol., N.Y., 94, 503.

Jart, Aa. (1959). Fette, Seif., Anstrichmitt. 6r, ro84.

Lambert, G. F., Miller, J. P., Olsen, R. T. \& Frost, D. V. (1958). Proc. Soc. exp. Biol., N. Y., $97,544$.

Wigand, G. (1959). Acta med. scand. 166, Suppl. no. 351 .

\section{EXPLANATION OF PLATES}

Plate I

(a) Transverse section of a medium-sized branch of the coronary arteries from a rabbit given cocoa butter with added cholesterol (group 3). Sudan black. The lumen of the artery is reduced to a narrow irregular opening by an atheromatous plaque, which appears deeply stained.

(b) Transverse section of a small and of a large branch of the coronary arteries from a rabbit given butterfat (group $\mathrm{r}$ ). Haematoxylin-eosin. The section of the large artery (top left) appears normal, whereas in the small artery the lumen is reduced to a narrow opening by an atheromatous plaque. The plaque appears essentially unstained after the procedure used for preparing the sections stained with haematoxylin and eosin.

\section{Plate 2}

Sections of rabbits' livers after 38 weeks on experiment:

(a) Dietary fat: cocoa butter with added cholesterol (group 3). Section cut on a freezing microtome and stained with Sudan black. The deeply stained areas around the central veins indicate a centrolobular lipid accumulation.

(b) Dietary fat: butterfat (group I). Section cut on a freezing microtome and stained with Sudan black. A deeply stained area around the central vein.

(c) The same liver as in (a). Unstained section, cut on a freezing microtome, seen under crossed nicols. The areas around the central veins appear light against a dark background, which indicates the presence of birefringent material, such as cholesterol and its esters.

(d) The same liver as in $(a)$. Section cut after paraffin embedding and stained with iron haematoxylin and van Gieson's stain. The initial stages of pathological changes are illustrated by light, swollen cells and by a condensation of reticular fibres round the central vein.

(e) Dietary fat: cocoa butter with added cholesterol (group 3). Section cut after paraffin embedding and stained with iron haematoxylin and van Gieson's stain. An advanced stage of pathological change is illustrated by strands of proliferated fibrous tissue dividing the liver into pseudolobuli. 
British Fournal of Nutrition, Vol. 16, No. 4

Plate I
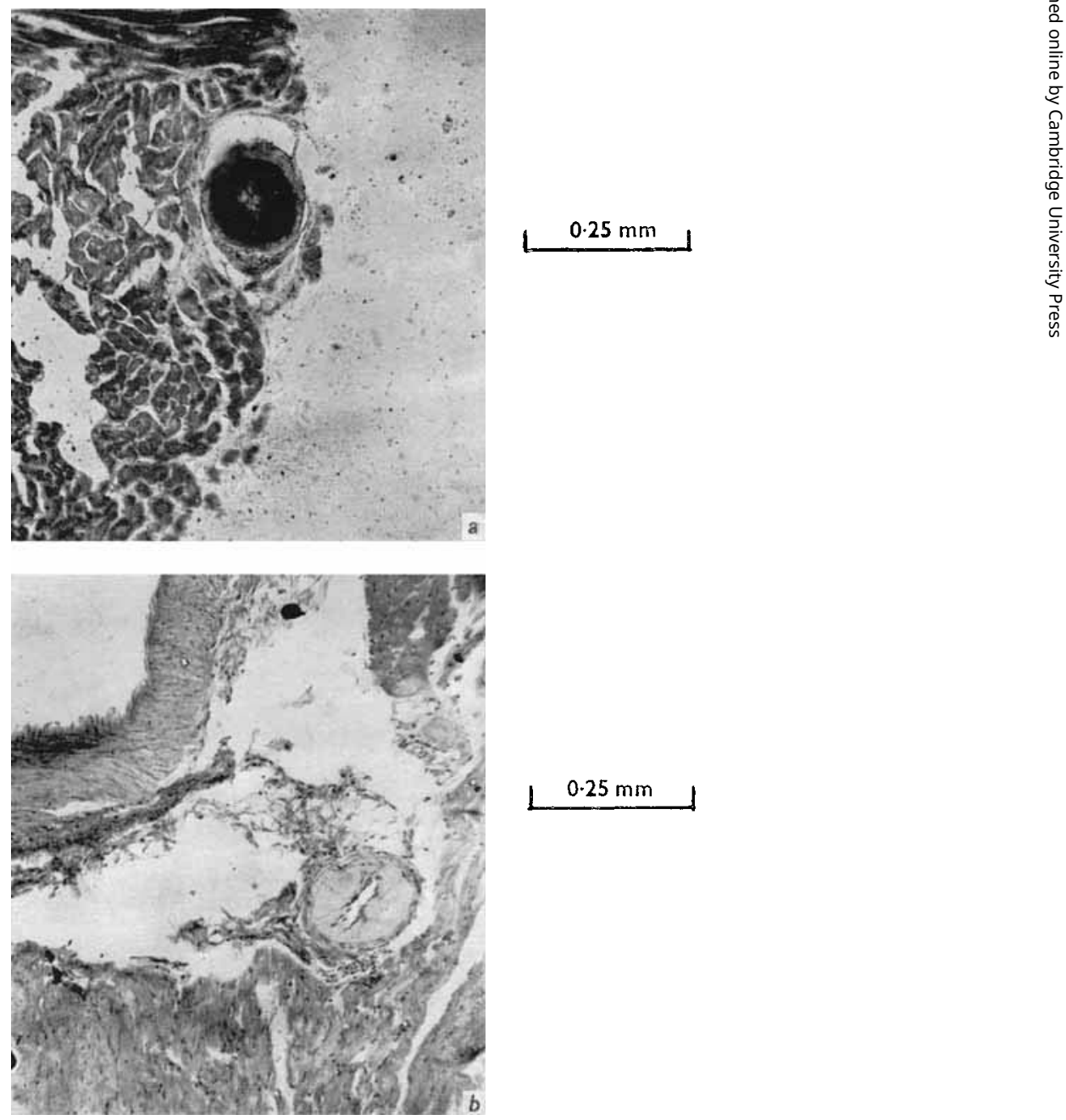

$0.25 \mathrm{~mm}$ 

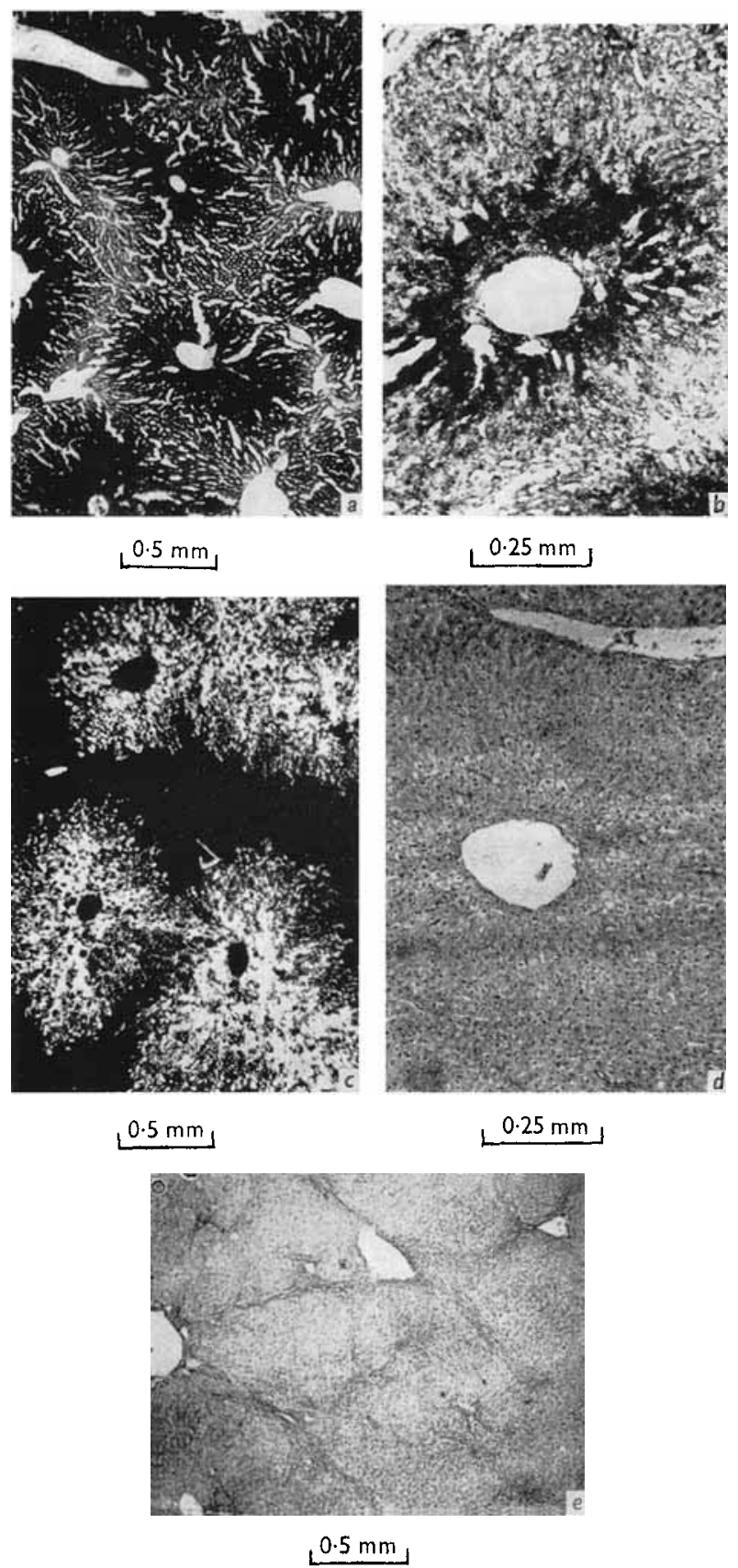

J. P. FUNCH, G. KRISTIENSEN AND H. IMAM 